\title{
Too Good to be True? The Expectations and Reality of Mine Development in Pajala, Sweden
}

\author{
Gregory A. Poelzer*, \\ Political Science, Luleå University of Technology \\ Thomas Ejdemo \\ Economics, Luleå University of Technology
}

\begin{abstract}
In order to achieve legitimacy, reality must match expectations. Resource development projects, such as mining, often force small communities to make difficult decisions regarding which projects to support or reject based on whether their expectations regarding the development of a mine manifest in reality. To make this assessment, this study looks at the factors that contributed to the legitimacy of a mine in northern Sweden, focusing on the community of Pajala, where a new mine opened in 2012. We conducted interviews with local residents representing different interests that aimed to draw out what legitimized or delegitimized the mine. From these interviews, we determined that economic factors weighed most heavily in generating support for the mine. Subsequently, in order to determine if these economic expectations matched reality, we examined economic performance data on the municipality. We found that many of the factors identified in the interviews related to local outcomes and that these matched closely with economic changes associated with the mine. Given the largely positive perceptions of the mine, the congruence between economic expectations and reality validate this support from the community. Thus, our results provide insight into the factors that affect legitimacy at the local level.
\end{abstract}

Keywords: Resource development; legitimacy; economic development; local economy; sustainable development

Responsible Editor: Hans-Kristian Hernes, UiT - The Arctic University of Norway, Tromsø, Norway.

Received: January 2017; Accepted: August 2017; Published: February 2018

\section{Introduction}

National and sub-national interests often serve as the driving force behind resource development. However, the greatest critical scrutiny of these projects arises at the

^Correspondence to: gregory.poelzer@1tu.se 
local level, and it is at this level that some of the most prominent legitimacy dilemmas materialize. Communities and individuals in close proximity to the mine experience the greatest effects, both positive and negative, which again induces discussions on whether or not the mine offers a net benefit. One of the common reference points in relation to attitudes towards mining is sustainable development. Referenced by both government and industry in relation to resource extraction, over the past three decades sustainable development has become an established marker for decisionmaking - balancing current needs against future risks. Stemming from the Bruntland Commission in 1987, the three pillars of sustainability: economic, social, and environmental, dominate many of the discussions on the impacts of resource development today, but the expectation remains that economic growth requires environmental and social trade-offs. However, there are different expectations regarding the kinds of impacts that these communities experience and, in turn, many different outcomes materialize. Therefore, looking at the congruence, or lack thereof, between expectations and reality provides insight into the sources of support for a mining project. Broadly, the aim of this paper is to understand why mining projects achieve legitimacy.

Economic factors such as employment and taxation remain salient issues when considering the viability of a mine and its effect on a local community. These considerations balance against potentially adverse outcomes to the environment, and the societal changes associated with a relatively large influx of highly paid residents. ${ }^{1}$ As a result, scrutiny at the local level becomes heightened, because developing a mine requires members of the local community to either support or reject its operations based on an evaluation of the trade-offs the project necessitates. On the one hand, a new mine may generate positive economic outcomes for the local community, which help alleviate some of the apprehension related to living in close proximity to the mine. On the other hand, social and environmental impacts may appear overwhelming or undesirable. It comes as no surprise, then, that possessing some control over the outcomes of these factors affects perceptions in the community. ${ }^{2}$ Understanding the interplay between these different factors, particularly the level of importance they receive in the community, not only gives insight into whether or not the local community will support a mining project, but also provides a more detailed rationale for why. Thus, the first task in this study is to investigate how these three factors: economic, environmental, and societal, are balanced against one another and which of these legitimize and delegitimize a mining project. Using this division allows us to compare how heavily economic, social, and environmental opportunities are weighed against risks and trade-offs often tied to sustainability. Further, we separate input legitimacy and output legitimacy, to reflect the differences between the planning and development stages of the mine to the operation of the mine. The first research question is: How are economic, environmental, and social factors balanced against one another with regard to legitimacy?

Discerning what factors affect legitimacy only covers part of the investigation. Looking at whether the expectations related to these factors come to fruition serves as the other component in this investigation on legitimacy. In order to achieve a high 
level of legitimacy, congruence must exist between the norms and beliefs of the people granting legitimacy and the actions and outcomes that occur in reality. ${ }^{3}{ }^{4}$ In this specific case, people living in the municipality of Pajala viewed the mine favourably; from the information gathered in the interviews, the project enjoyed a relatively high level of legitimacy as people perceived its opening as a net positive for the community. Therefore, along with identifying the factors that legitimize the mining project, we look at the related outcomes, comparing the specifics on what types of impacts residents expect from the mine to the on-the-ground reality. The second research question is: To what extent do legitimizing expectations align with reality?

Together, these research questions aim to expand our understanding of legitimacy, particularly within the context of resource development. In order to accomplish this task, first we provide an overview of the case, Pajala, and some of the broader context of the mining industry at the time. Second, we cover the theoretical underpinnings of this study along with the framework and methodology. Third, we outline the findings of our interviews, categorize them and identify the most important factors. Fourth, we compare the factors from the interviews with measurable, observable outcomes to determine the extent to which these expectations were fulfilled. Fifth, and finally, we discuss the implications of these findings for the mining industry and legitimacy research more generally.

\section{Case Background}

With a history that spans centuries coupled with strong state involvement over the past few decades, it comes as no surprise that Sweden currently leads the European Union (EU) in iron ore production and is also a major producer of copper, zinc, lead, gold, and silver. Throughout most of the twentieth century, however, the Swedish Government restricted mining operations to domestic companies - the most prominent being a state-owned company, Luossavaara-Kiirunavaara Aktiebolag (LKAB).

Through the introduction of new mining legislation in 1991, Sweden signaled the end of restricting foreign investment in the country's mining industry. ${ }^{5}$ However, new investments in mining projects requires more than new legislation. Unsurprisingly, global mineral prices needed to reach a certain level before interest waxed. In the late 2000s, a surge in commodity prices resulted in a mining boom as the price of iron futures reached over $\$ 180$. As a result, expenditure on exploration in Sweden grew from just under 300 million SEK (37.7 million USD) in 2005 to a high of just under 800 million SEK (113.1 million USD) in $2011 .{ }^{6}$ We look at one mining project that came as a result of this new investment, Northland Resources, and its mine in the municipality of Pajala.

Pajala is a town in northern Sweden, located in northeast Norrbotten County next to the Finnish border. The area is known as the Torne Valley, after the large Torne River, which flows through Pajala and continues $180 \mathrm{~km}$ south towards the Bothnian Bay. South of Pajala, the river forms the border between Sweden and Finland. A historical centre of trade due to its location near several major rivers in the region, Pajala's main economic activities historically include reindeer herding by the indigenous 
Sami people, agriculture, and iron works. ${ }^{7}$ In more modern times, the local labour market depended on public sector activities and forestry, which long served as the backbone of the local economy. The municipality of Pajala currently comprises a central town and several villages. As in many other similar municipalities, new technology and structural changes during the 1950s and -60s caused a loss of employment opportunities and initiated a process of depopulation. People started to migrate from Pajala to jobs elsewhere, causing the population to decrease from 15400 inhabitants in 1954 to the current population of 6303. Over the past few decades, young people have continued to leave to pursue opportunities not available to them in Pajala (for example jobs, education etc.). As a consequence, the local government has had to cope with one of the highest shares of elderly residents in all of Sweden. The municipality has also experienced a deficit of women, and birth rates have not been sufficient to balance the declining demographic development. This social development long pointed towards a gloomy outlook for the region. One example is a local road sign supposedly put up some time in the 1970s, saying "The last one to leave turns off the lights!" although we have not been able to verify its existence.

The region appeared to rebound when Northland Resources, a junior mining company initially based in Canada, indicated its interest in developing an iron ore mine in Kaunisvaara, just north of Pajala. Northland started construction at the mine site in 2010 and began operations in December 2012 at the Tapuli deposit. This new mine was widely reported on in the news media as a potential catalyst to reverse some of the decline experienced in recent decades. ${ }^{9}$ Jakobsson conducted a survey on future expectations in Pajala, when the Kaunisvaara mine was in the planning stage. ${ }^{10}$ The results showed that the community was strongly positive toward the plans for a mine and that the level of support was interlinked with socio-economic trends and expectations.

The company was in the process of developing the Sahavaara deposit in 2014 and moving towards full production, when severe liquidity issues and falling iron ore prices forced the mining company to file for bankruptcy in the fall of 2014, raising questions about future ownership and operations. Nevertheless, strong community support for the mine continues, largely due to the efforts of Northland early in the planning process to create an open dialogue with the inhabitants of Pajala.

\section{Theory and Methods}

In traditional political thinking, legitimacy speaks to the relationship between the governor and the governed. Those in authority enjoy legitimacy when they operate in a manner that citizens view as right, just, and proper. Therefore, feedback from citizens serves as the primary determinate of whether or not government is living up to their expectations. ${ }^{11}$ However, as policy decision-making changes, the number of actors and interests that can affect the outcome grows and, as a result, the strong connection between governor and governed fades with regards to legitimacy. ${ }^{12}$ For resource development cases that require consideration of multiple interests and 
outcomes, such as mining, the relationship between the governor and the governed becomes increasingly blurred; important factors affecting legitimacy exist beyond the relationship between citizens and the state. The interaction between different actors during the process of mine development and the outcomes during production all affect the legitimacy of a mine. In this respect, local communities face the important, and difficult, task of determining what legitimizes a mining project. Is a positive relationship with a mining company significant enough to offset the loss of usable land or water? What kind of economic development will the mine produce? These types of questions accompany most mining projects but the specifics around these issues vary. Therefore, we further develop our definition of legitimacy in order handle context specific issues and operationalize it for our study.

In many respects, the general public has the power to reward or punish the actions of governments and politicians. The most straightforward tool the public has to confer legitimacy comes in the form of elections; policy decisions and outcomes that run counter to the values of society will not be tolerated for extended periods of time. Thus, legitimacy remains one of the central goals for policymakers - both politicians and bureaucrats - as they look to achieve strong levels of support, acceptance and/ or compliance. ${ }^{13}$ Further, as legitimacy grows, the need for coercion shrinks. Some even argue that legitimacy requires compliance devoid of threats of disciplinary ac-

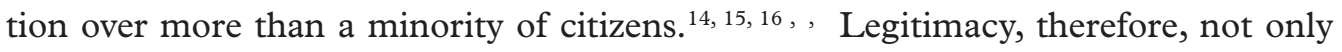
provides a measure of performance, but is also a necessary condition for successful policy.

Expanding on compliance, North makes the argument that, "The costs of maintenance of an existing order are inversely related to the perceived legitimacy of the existing system. To the extent that the participants believe the system fair, the costs of enforcing the rules and property rights are enormously reduced." ${ }^{17}$ Given the connection between support, compliance, and cost, the importance of legitimacy cannot be overstated. This becomes particularly pertinent in jurisdictions with economies reliant on resource extraction. But the value of legitimacy extends beyond policy makers. Corporations, interest groups, and individuals all strive for legitimacy, but may simultaneously enjoy different levels of legitimacy. Again, their legitimacy rests on how they are perceived by their respective constituents, but the types of interaction that occur and methods for holding actors accountable differ from sector to sector; creating different types of legitimacy. In an industry such as mining, where a confluence of activity takes place during the development and operation of a mine, it becomes reasonable to account for these different relationships and broaden the scope of both the actors and the process. Therefore, finding a definition of legitimacy that casts a wider net, one beyond political legitimacy, becomes paramount.

To begin with, we build on Suchman's oft-used description: "Legitimacy is a generalized perception or assumption that the actions of an entity are desirable, proper, or appropriate within some socially constructed system of norms, values, beliefs, and definitions." ${ }^{18}$ Key to this conceptualisation of legitimacy is the recognition of 
the importance of norms, values, beliefs, and definitions and, more importantly, that variation exists. Societies, communities, and organizations hold different beliefs and consequently develop unique norms. Context, history, and tradition are a few of the many forces that create diversity, and accounting for these differences becomes key to understanding how what might be completely acceptable in one community may be completely abhorrent in another. Thus, the rules that govern a society and the outcomes of these rules should reflect the norms and interests of that society. ${ }^{19} \mathrm{How}-$ ever, for this study we focus on a single issue, a new mine, and instead of looking at the general norms, values, and beliefs these individuals hold regarding government, resource extraction, the mining industry, and public consultations, we look at attitudes specific to the mine. And, in order to draw out some of the norms and beliefs of the respondents we ask about their value expectations - the standards by which they expect others to operate and the outcomes of these operations. Value expectations serve as an effective proxy for norms, values, and beliefs, from which respondents base their perceptions of the mine. To assess whether the mining project lives up to these value expectations, we also look at the outcomes on the ground, the realities of establishing and operating that come with a new mine. Through this conception of legitimacy, we end up with expectations on one side and reality on the other. As expectations and reality become more congruent, legitimacy increases. Figure 1 is a depiction of this relationship.

Many of the considerations that affect the legitimacy of a mining project coincide closely with sustainable development, and, accordingly, we categorize respondents' expectations along three dimensions: economic, environment, and social. Because of the inherent long-term impacts, including irreversible changes related to land development, we underscore the significance of recognizing both the development process and outcome during the mine operation with respect to legitimacy. Operationalizing these separate issues, however, requires additional qualification of our concept of legitimacy.

The distinction between input and output as the two dimensions of legitimacy provides a solid foundation for categorization; input legitimacy refers to the mechanisms for public participation in political institutions, while output legitimacy refers to the level of public support for the results these same institutions produce. ${ }^{20}$ While input legitimacy ties in closely with process, and acknowledges the demands of citizens and

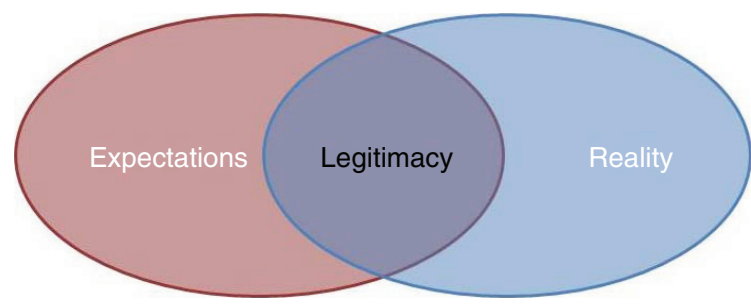

Figure 1. Overlap between value expectations and reality produces legitimacy 
develops mechanisms to address these same demands, output legitimacy conversely depends on the product of a decision or outcome.

In order to gather information on the perceptions of local residents on the legitimacy of Northland Resources and its mining project, we conducted semi-structured, face-to-face interviews between November 2013 and June 2014 in Luleå, Pajala, and Kaunisvaara. The interviewees were a targeted sample in order to include diverse and prominent interests in the community. We selected municipal administrators, members of local environmental conservation organizations, a representative from the reindeer herding community, a small business owner, and local residents who had participated in some of the public consultations. We also conducted an interview with a company executive for additional information on the planning and operation of the mine. While not representative of the whole community, these respondents represent a broad range of interests and, most importantly, possess significant knowledge of both the development process and the mining operations. Importantly, the individuals selected lived in the municipality before the permitting process began. The semi-structured interviews focused on questions about how the development process worked and how the mine affected the community, in particular positive and negative aspects of the mine - its potential benefits and risks. Interviews lasted between 30 minutes and 11/2 hours.

We opted to utilize a qualitative approach through in-depth interviews, rather than gather quantitative data through a survey, for several reasons. First, asking questions about expectations and experiences potentially leads to larger variation in responses. Qualitative data collection, particularly through semi-structured interviews, also avoids the issue of researchers pre-determining relevant issues connected to legitimacy. Second, interviews allow for follow-up questions, which is a necessity when investigating the details of expectations.

\section{Findings}

\section{i. Economic, Environmental, and Social Factors}

In order to categorize our results, we first organized interviewee responses according to whether they related to the process of developing the mine or to changes created by its development. From there, we organized our findings into legitimizing and delegitimizing factors. Table 1 provides an overview of responses, categorized according to this scheme. The legitimizing factors correspond to responses that refer to the process of developing the mine or to the effects of the mine in a positive light. Conversely, the delegitimizing factors indicate fear of or skepticism about the project. During the interviews, it quickly became evident that there was a strong perception that the mine had had a positive influence on the community. Analyzing and organizing the data from the interviews further validated this finding.

As expected with natural resource development, economic factors fell into the legitimizing column while environmental factors fell into the delegitimizing column. This occurred both on the input side and the output side. Further, because the mine 


\section{Gregory A. Poelzer E Thomas Ejdemo}

Table 1. Issues Affecting Legitimacy

\begin{tabular}{|c|c|c|c|}
\hline \multicolumn{2}{|c|}{ Input Factors } & \multicolumn{2}{|c|}{ Output Factors } \\
\hline Legitimizing & Delegitimizing & Legitimizing & Delegitimizing \\
\hline $\begin{array}{l}\text { Initial reaction was very } \\
\text { positive (personal as well } \\
\text { as the community) } \\
\text { Northland has provided } \\
\text { information continuously } \\
\text { and reached out/listened } \\
\text { to local people } \\
\text { Northland seems to have } \\
\text { been embraced by the } \\
\text { community }\end{array}$ & $\begin{array}{l}\text { Most people have been } \\
\text { very positive, but there } \\
\text { are a few that have been } \\
\text { openly negative towards } \\
\text { mining (environmental } \\
\text { concerns) }\end{array}$ & $\begin{array}{l}\text { New jobs: Currently } \\
\text { about } 100 \text { at the Juno- } \\
\text { suando "transport hub" } \\
\text { which will increase to } \\
250-300 \text {, and there will } \\
\text { be } 250-300 \text { workers at } \\
\text { the mine, perhaps even } \\
400 \text { (at full production) }\end{array}$ & $\begin{array}{l}\text { New housing is necessary } \\
\text { so people can live and } \\
\text { work here (and pay tax), } \\
\text { we do not want fly in/ } \\
\text { fly out }\end{array}$ \\
\hline $\begin{array}{l}\text { "Name a minister who } \\
\text { has not been here" }\end{array}$ & $\begin{array}{l}\text { Concern about long term } \\
\text { impact on Sami lifestyle } \\
\text { and reindeer herding }\end{array}$ & $\begin{array}{l}\text { Cliffton (which handles } \\
\text { the ore transports) has } \\
\text { organized their roster so } \\
\text { that their drivers have to } \\
\text { live nearby (within a daily } \\
\text { commute) }\end{array}$ & Increased traffic \\
\hline $\begin{array}{l}\text { We feel that the mining } \\
\text { company is trustworthy }\end{array}$ & $\begin{array}{l}\text { Lack of effort/recognition } \\
\text { from municipality for } \\
\text { Sami village }\end{array}$ & $\begin{array}{l}\text { There has been no in- } \\
\text { crease in crime rates }\end{array}$ & Dust \\
\hline $\begin{array}{l}\text { If the company had not } \\
\text { behaved well, we would } \\
\text { be under tremendous } \\
\text { pressure, but we have } \\
\text { not experienced anything } \\
\text { like that (i.e. complaints } \\
\text { about the company) }\end{array}$ & $\begin{array}{l}\text { Concerned about North- } \\
\text { land's financial problems. } \\
\text { What if some other } \\
\text { company buys the mine } \\
\text { that might not respect } \\
\text { the Sami? }\end{array}$ & $\begin{array}{l}\text { Stores are able to stay } \\
\text { open later during the day }\end{array}$ & $\begin{array}{l}\text { Difficult for the public } \\
\text { sector to compete with } \\
\text { mining wages } \\
\text { Some people have had } \\
\text { to move from the mining } \\
\text { area (they negotiated } \\
\text { with Northland but we } \\
\text { have nothing to do with } \\
\text { it) }\end{array}$ \\
\hline $\begin{array}{l}\text { Northland wants their } \\
\text { employees to become } \\
\text { integrated in the } \\
\text { community }\end{array}$ & & $\begin{array}{l}\text { Improved roads and road } \\
\text { maintenance }\end{array}$ & $\begin{array}{l}\text { Communication efforts } \\
\text { from the company have } \\
\text { slowed down somewhat } \\
\text { since they have begun } \\
\text { producing }\end{array}$ \\
\hline $\begin{array}{l}\text { Many information meet- } \\
\text { ings, well attended }\end{array}$ & & $\begin{array}{l}\text { The community has } \\
\text { become more "living", } \\
\text { empty houses have been } \\
\text { rented out }\end{array}$ & $\begin{array}{l}\text { Some concern about } \\
\text { potential negative impact } \\
\text { on water quality in river }\end{array}$ \\
\hline $\begin{array}{l}\text { Good relations and } \\
\text { dialogue with local } \\
\text { government }\end{array}$ & & $\begin{array}{l}\text { There were a lot of work- } \\
\text { ers here during construc- } \\
\text { tion (nearly } 800 \text { ), positive } \\
\text { for restaurants etc. } \\
\text { Some new families have } \\
\text { moved here. }\end{array}$ & $\begin{array}{l}\text { People who live near the } \\
\text { road have complained } \\
\text { about dust from road } \\
\text { transports (says North- } \\
\text { land addressed the issue } \\
\text { quickly) }\end{array}$ \\
\hline $\begin{array}{l}\text { There were many meet- } \\
\text { ings about how to house } \\
\text { the temporary workforce } \\
\text { before }\end{array}$ & & $\begin{array}{l}\text { The population has in- } \\
\text { creased for the first time } \\
\text { in many years }\end{array}$ & $\begin{array}{l}\text { Some concern about } \\
\text { truck transports, would } \\
\text { prefer railway (better for } \\
\text { the environment) }\end{array}$ \\
\hline
\end{tabular}


Table 1. (Continued)

\begin{tabular}{|c|c|c|c|}
\hline \multicolumn{2}{|c|}{ Input Factors } & \multicolumn{2}{|c|}{ Output Factors } \\
\hline Legitimizing & Delegitimizing & Legitimizing & Delegitimizing \\
\hline \multicolumn{2}{|l|}{$\begin{array}{l}\text { Good info from North- } \\
\text { land, good relationship } \\
\text { between company and } \\
\text { community }\end{array}$} & $\begin{array}{l}\text { People have totally differ- } \\
\text { ent attitudes, views and } \\
\text { expectations about the } \\
\text { future today compared } \\
\text { to just a few years ago } \\
\text { (more positive now). This } \\
\text { is evident in how people } \\
\text { are building and reno- } \\
\text { vating their homes, the } \\
\text { municipality has invested } \\
\text { in new playgrounds and } \\
\text { in little things such as } \\
\text { new Christmas lights } \\
\text { above the streets in town, } \\
\text { after having the same old } \\
\text { ugly lights for } 30 \text { years. }\end{array}$ & $\begin{array}{l}\text { Lack of housing is an } \\
\text { important bottleneck, } \\
\text { it prevents people from } \\
\text { moving here. Most } \\
\text { people in the housing } \\
\text { queue are between 25-35 } \\
\text { years old. }\end{array}$ \\
\hline \multirow[t]{8}{*}{$\begin{array}{l}\text { Northland has conducted } \\
\text { themselves well, kept us } \\
\text { well informed and main- } \\
\text { tained a good dialogue }\end{array}$} & & $\begin{array}{l}\text { Many local employees at } \\
\text { the mine }\end{array}$ & $\begin{array}{l}\text { Some people had to } \\
\text { move from their home } \\
\text { in Kaunisvaara (but they } \\
\text { have accepted it as a } \\
\text { necessary thing) }\end{array}$ \\
\hline & & $\begin{array}{l}\text { Positive to see so many } \\
\text { young people who want } \\
\text { to live and work here }\end{array}$ & $\begin{array}{l}\text { Some people have lost } \\
\text { money on Northland } \\
\text { shares (due to financial } \\
\text { problems) }\end{array}$ \\
\hline & & New jobs & $\begin{array}{l}\text { We have noticed in- } \\
\text { creased vegetation on the } \\
\text { river bottom }\end{array}$ \\
\hline & & Improved roads & $\begin{array}{l}\text { A healthy river can } \\
\text { provide opportunities for } \\
\text { tourism, which can last } \\
\text { longer than a mine }\end{array}$ \\
\hline & & $\begin{array}{l}\text { Many visitors/temporary } \\
\text { workers spent money } \\
\text { during construction (at } \\
\text { restaurants etc) }\end{array}$ & $\begin{array}{l}\text { Northland has ongoing } \\
\text { financial issues and we } \\
\text { always hear that they } \\
\text { need to raise more } \\
\text { money. What if they go } \\
\text { bankrupt? Is someone } \\
\text { else taking over? }\end{array}$ \\
\hline & & $\begin{array}{l}\text { Local companies have } \\
\text { expanded thanks to the } \\
\text { mine }\end{array}$ & \\
\hline & & $\begin{array}{l}\text { Jobs, all my family have } \\
\text { jobs now. If they are not } \\
\text { working at the mine they } \\
\text { are working in something } \\
\text { related to the mine. }\end{array}$ & \\
\hline & & $\begin{array}{l}\text { Pajala can continue to } \\
\text { exist and services can be } \\
\text { maintained }\end{array}$ & \\
\hline
\end{tabular}


was largely viewed as positive, economic factors brought up in the interviews outnumbered environmental factors to a considerable extent. However, an unexpected finding was that social factors also legitimized the mine, which in many ways goes hand-in-hand with the economic outcomes. Bringing in new, young residents to the area had improved the spirit of the community. The table includes specific comments given by respondents during the interviews and provides a sense of the importance of the economic versus environmental or social issues.

The table above gives some of the specific insights into the issues raised by the residents of Pajala. This table is by no means exhaustive but the responses included are indicative of the overall sentiment we perceived when conducting the interviews, as well as when we engaged in more casual conversations. One of the most notable findings is the lack of delegitimizing factors on the input side. Northland Resources engaged heavily in dialogue with local residents, interest groups, and reindeer herders. These engagement efforts appear to have paid off. On the output side, respondents focused primarily on the local impacts of the mine. On the positive side, employment dominated the discussions, while on the negative side, local environmental issues related to water quality and dust were a matter of concern. These responses come as little surprise, as the debate on resource development often echoes the divisions of sustainable development. Importantly, a few references were made to the financial difficulties Northland Resources found itself in and the potential consequences of these problems. However, the consequences discussed focused on whether a new company would prove as trustworthy as Northland.

Given the clear and unanimous response in the interviews that the mine represented a positive development for the community, along with the overwhelming connection between positive perceptions and economic factors, the next step in the analysis is to look at whether expectations matched reality. The next sub-sections look at economic data related to the responses we received.

\section{ii. Quantitative Analysis of Economic Development in Pajala}

Based on the significant numbers of responses that point to the economy as the rationale for the legitimacy of the mine, we examine economic development in Pajala during the short lifespan of the mine. The years of comparison for the economic analysis are 2009 and 2014. This captures the year right before construction of the mine site started and the last year of production, until the bankruptcy. The economic indicators utilized cover population development, employment (per industry), labour market participation and income (growth in sum of wages per capita). We also employ a dynamic shift share analysis to provide empirical evidence on how employment growth in Pajala during the mining era was influenced by factors specific to the local economy, as well as the influence of national and county-level trends.

First, to provide additional background information we highlight the population development in Pajala from the late 1960s in Figure 2. The main reason for the declining population levels of the $1960 \mathrm{~s}$ and $70 \mathrm{~s}$ is out-migration caused by structural 


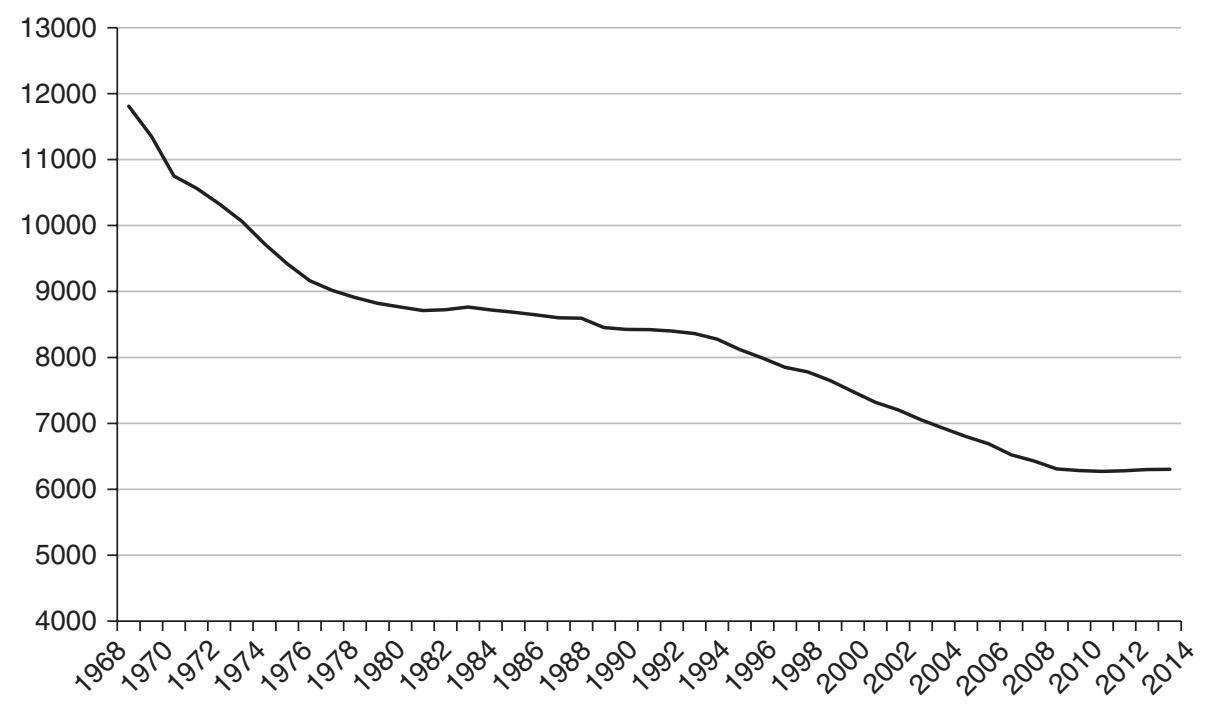

Figure 2. Population development in Pajala, 1968-2014

Source: Statistics Sweden

Table 2. Selected indicators on recent economic development in Pajala

\begin{tabular}{|c|c|c|c|c|c|c|c|c|}
\hline & \multirow{2}{*}{\multicolumn{4}{|c|}{ Income (sum of wages) per capita ${ }^{\star}$}} & \multicolumn{4}{|c|}{ Labor market participation rate ${ }^{\star \star}$} \\
\hline & & & & & \multicolumn{2}{|c|}{2009} & \multicolumn{2}{|c|}{2014} \\
\hline & 2009 & 2013 & $\begin{array}{l}\text { Growth, 2009- } \\
2013\end{array}$ & $\begin{array}{l}\text { Average annual } \\
\text { growth (\%) } \\
2009-2013\end{array}$ & Men & Women & Men & Women \\
\hline Pajala & 98.4 & 121.9 & 23.5 & $6.00 \%$ & $73.8 \%$ & $72.4 \%$ & $82.90 \%$ & $81.00 \%$ \\
\hline Sweden & 138.6 & 149.2 & 10.6 & $1.90 \%$ & $76.2 \%$ & $73.1 \%$ & $78.5 \%$ & $76.0 \%$ \\
\hline
\end{tabular}

* thousand SEK in constant (2013) prices, ${ }^{\star \star \%} \%$ of people aged $20-64$

Source: Statistics Sweden (own adaption)

change and increasing urbanization. Pajala as well as many other non-metropolitan areas of Sweden have faced challenges such as: an ageing population; an increasingly challenging demographic structure (i.e. 'natural population change'), and; out-migration of young people due to lack of jobs and opportunities. As Figure 2 shows, the negative population trend which had persisted for decades petered out around 2010, in conjunction with the development of the mine.

In our interviews, respondents emphasized that the mine had a significant impact on local employment and economic development during its few years in production, until the bankruptcy. This is supported by official statistics. Table 2 provides a summary of some key economic indicators for Pajala compared to national data. As the data shows, incomes (measured here as the sum of wages per capita) were still lower than the national average in 2013 but grew at a much faster rate than the national 


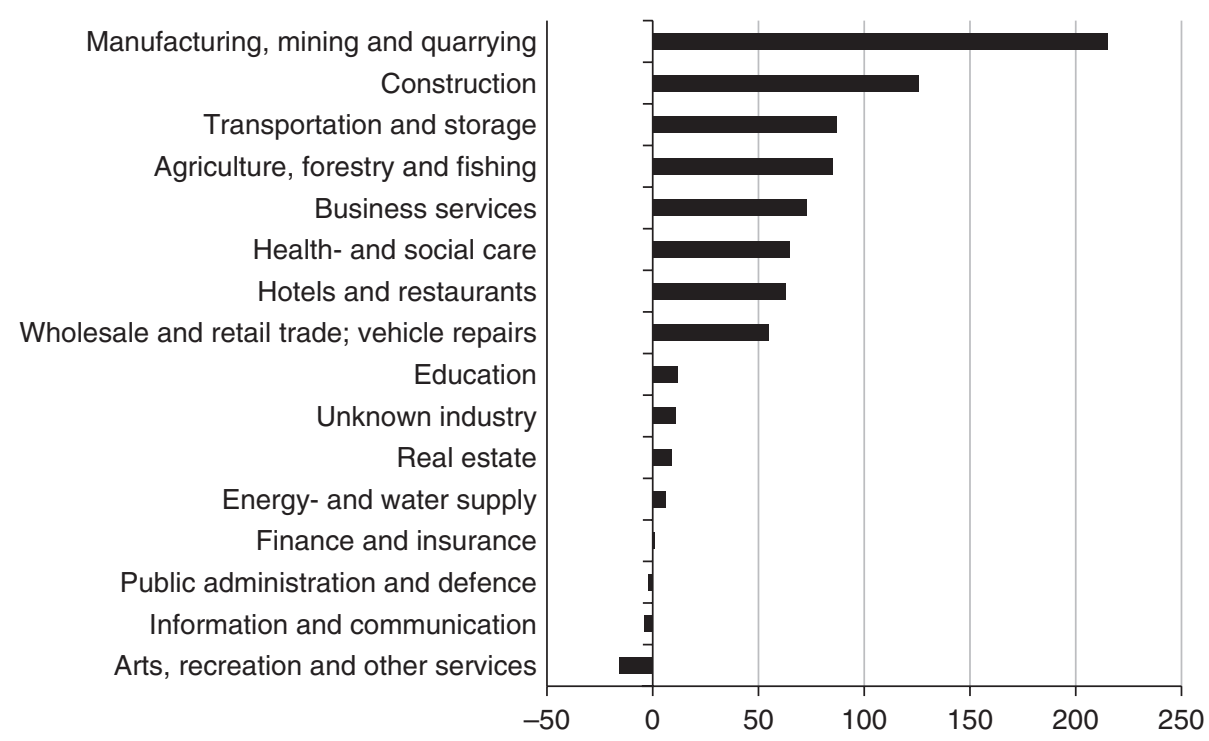

Figure 3. Employment changes in Pajala by industry, 2009 to 2014 (no. of jobs)

Source: Statistics Sweden (own translation)

average between 2009 and 2013. Data for 2014 was not yet available when these income growth indicators were calculated. The table also shows that labor market participation rates improved considerably for both men and women during the years 2009-2014 and in fact exceeded national averages by the end of this time period.

In absolute terms, local employment growth between 2009 and 2014 totalled 786 new jobs. This reflects a total employment growth of $36 \%$. Figure 3 displays how the change in employment between 2009 and 2014 was distributed by main industry. Between 2009 and 2014, employment increased in nearly all sectors. The major growth industries were mining, construction, transportation, agriculture and forestry, and business services.

\section{iii. Exploring local employment growth: a dynamic shift-share analysis}

The data reviewed above shows that the development of the mine coincided with a period of rapid employment growth in Pajala. Much of this effect is most likely attributed to the mine, but the influence of regional and national economic development on local employment remains unclear. To address this, we employ the shift-share method to our empirical analysis. According to Stimson et al., ${ }^{21}$ the technique "...enables the assessment of a region's overall performance relative to other regions". It does so by examining development in the study region with respect to a reference area (typically the nation). In our case, we examine employment growth in Pajala with respect to two separate reference areas: the surrounding region (Norrbotten county) and the nation (Sweden).

The shift-share method is used to decompose local employment growth during the period 2009-2014 into three components (as described by Stimson et al. ${ }^{22}$ ): (a) the 
national share, which captures that part of change attributable to overall national trends (or county-level trends); (b) the industry mix effect, which captures that part of change attributable to the industrial composition of the region - i.e. employment change due to local industries which are growing quickly or slowly at the national (or county) level, and; (c) the regional (local) shift (sometimes referred to as 'competitive', 'differential' or 'local' effect), which measures the proportion of employment growth attributable to effects specific to the study region (local effects, in this case). This component is often interpreted as evidence of some kind of comparative advantage which enhances the competitiveness of the local economy. ${ }^{23}$

To overcome some of the limitation ${ }^{24}$ associated with the traditional comparative static shift-share method (i.e. it only examines the first and final years studied), we employ the dynamic approach suggested by Barff and Knight, ${ }^{25}$ where shift-share components are computed annually and summarized over the study period. A more detailed technical description is available in the appendix. Relatively recent applications of the dynamic shift-share analysis include Mitchell and Carlson, ${ }^{26}$ who explore regional employment growth in Australia; Hirobe who examines inter-regional disparities of the US labor market, ${ }^{27}$ and; Otsuka, who employs a dynamic shiftshare framework to analyze regional energy demand in Japan. ${ }^{28}$ The following section presents the main results of the analysis.

\section{iv. Results}

This section reviews the results of the dynamic shift-share analysis. We focus solely on aggregate annual results, as the intention in this section is to examine overall economic performance in Pajala relative to the reference areas. This analysis is provided in order to ascertain if the positive development observed in section $i i$ was in fact largely due to the mine (i.e. conditions specific to Pajala), or a result of county- or national level growth trends. Figure 4 illustrates the annual results for each component, with Sweden as the reference economy.

Following Stimson et al. ${ }^{29}$ the interpretation is relatively straightforward: the national growth effect suggests that a total of 194 local jobs can be attributed to the overall growth of the Swedish economy during the period, but the effect is declining. The industry mix effect suggests that 32 new jobs were added over the period as a result of the industrial composition (i.e. specialization in industries which outperformed the overall national growth rate). This effect is more or less neutral except for 2011. The industry-specific effects (not provided here) show that the effect can mainly be traced to agriculture and forestry, with a likely explanation being a change in the classification of individuals employed in the sector in $2011 . .^{30}$

The most interesting result of the shift-share analysis is the 'local effect', which indicates that 560 local jobs were added due to effects specific to the study region (Pajala). The standard interpretation of shift-share suggests that this is evidence of some kind of comparative or competitive advantage, but it does not reveal the actual source. In this case we know that the major factor was the development of the Kaunisvaara project 


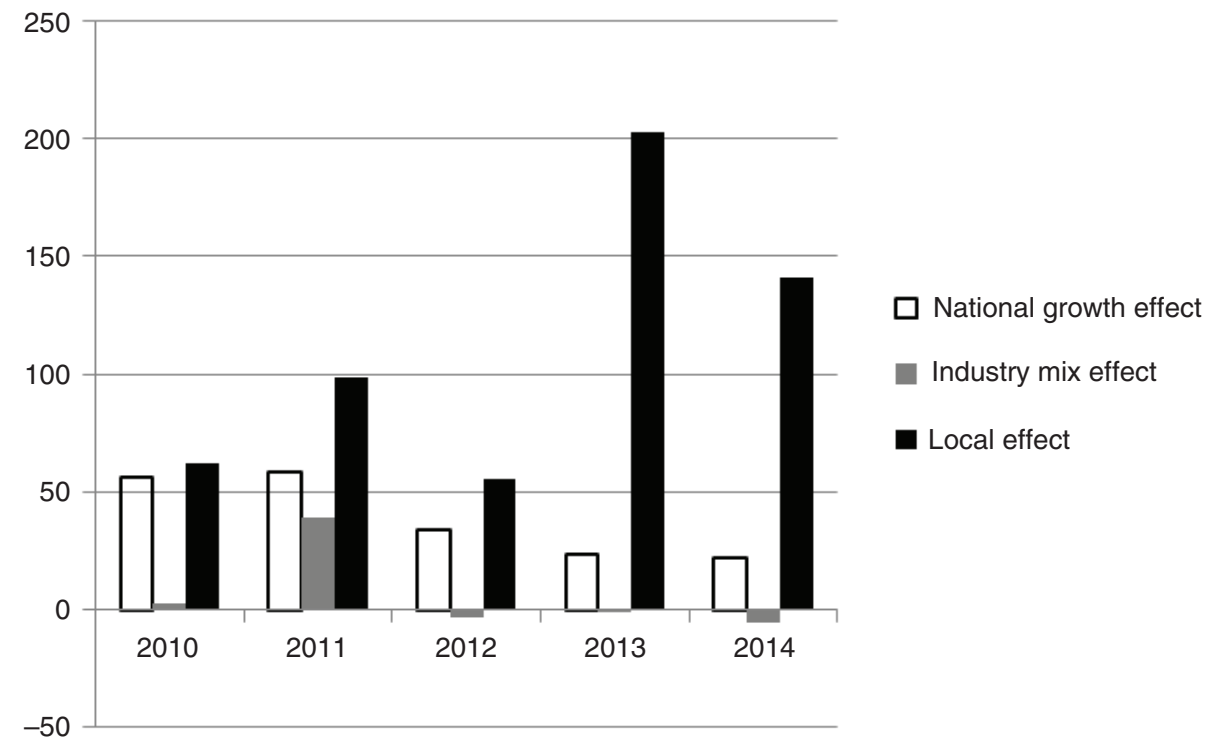

Figure 4. Annual shift-share components for employment growth in Pajala with respect to national development

into an operating mine during the period. The industry-specific local effects (not provided here) clearly show that the major factor behind the strongly positive local effect was employment growth in manufacturing and extraction (i.e. mining) and in other parts of the mining industry's value chain (construction; transportation and storage).

We now move on to the second part of our dynamic shift-share analysis, where we use Norrbotten county as the reference area. Figure 5 illustrates the results for the annual shift-share components. The main difference here is that we examine the influence of trends at the county level rather than national trends.

A greater proportion of local employment growth can clearly be attributed to countylevel trends compared to the influence of overall national growth during the period. The aggregate 'county growth effect' is 230 jobs, but the effect is declining during the period. The effect of industry mix is also similar, although slightly larger in 2011 when using the county as reference. Again, the most interesting results are the 'local effects', which describe the proportion of employment growth that can be attributed to factors specific to Pajala. Over the period, the local effect was 510 jobs according to the analysis.

Overall, the indicators and analyses we review in this section further support the argument that mining enhanced economic development in Pajala. Our dynamic shift-share analysis provides empirical evidence which shows that the local economy outperformed the county as well as the nation in terms of employment growth during the mining era. The mine appears to have had important direct as well as indirect impacts on the local labor market. However, the new jobs came at the expense of making Pajala an increasingly resource dependent community and exposed the local economy to volatile global commodity markets. As Figure 6 depicts, iron ore only 


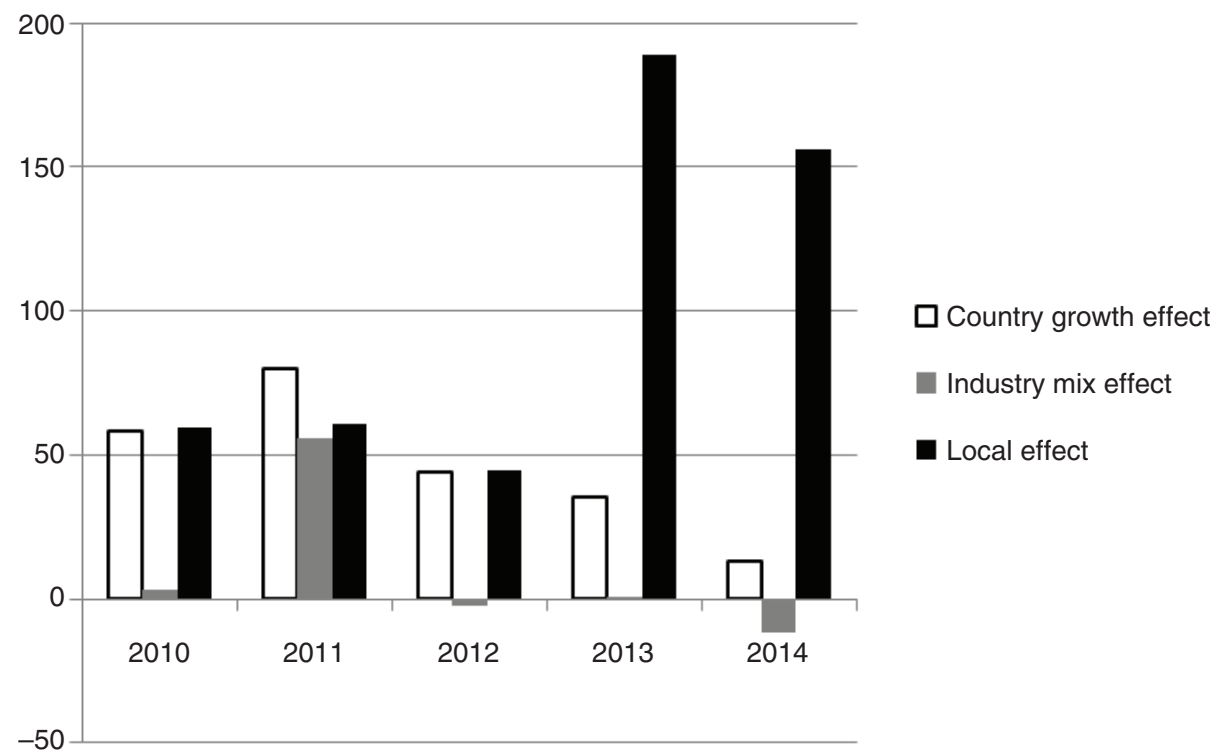

Figure 5. Annual shift-share components for employment growth in Pajala with respect to countylevel development

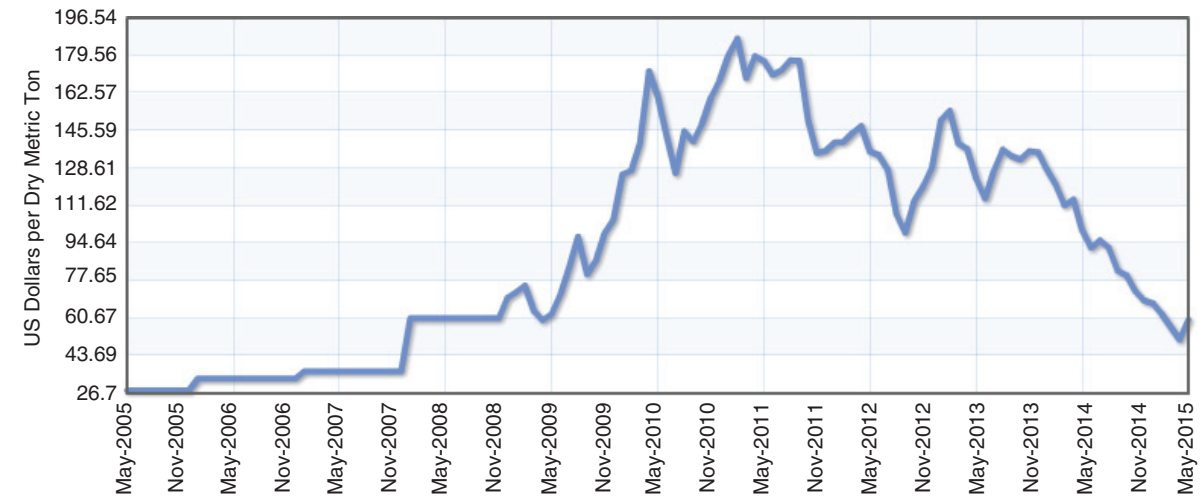

Figure 6. Ten year history of futures prices for iron ore

enjoyed a temporary high in price which was enough to spur to new projects but not long enough to sustain many. The impact of the bankruptcy in late 2014 has not been analyzed empirically in this study due to lack of data.

\section{Discussion}

As this paper shows, the local economy in Pajala - and in a sense, the community in general - was revived by the Kaunisvaara mine. Our analysis of government statistics 
support the notion that mining had a significant impact on the local economy, beyond providing jobs directly. This brings us back to the question of legitimacy.

Looking at the responses provided in the interview process on the input side, local residents expected not only to receive information regarding the development of the mine, but also to influence decision making to some degree. In this regard they appeared to be satisfied. The strategy Northland utilized, becoming very familiar and even familial, made a significant difference according to the individuals we interviewed. Thus, because of this interaction, including the willingness of the company to solve problems, a high level of trust was established during the development process. Environmental concerns comprised the bulk of the delegitimizing issues but the social benefits far outweighed these concerns overall.

On the output side, the primary consideration of the local residents concerned the economic benefits derived from the mine - it was the driving force behind the legitimacy of the mine for the community. Many of the key issues brought forward related to the growth of local employment either directly or indirectly through the mine. In this respect, the match between the salient issues raised by the local community and economic reality matched closely. Even further, economic growth precipitated many of the perceived social benefits. As a municipality with a shrinking population, anxiety existed over its future. In this case, the influx of residents represented a potential revitalization of the community - a perceived positive social change. This finding may speak to how social outcomes are viewed with regard to sustainable development. In cases where economic outcomes are more important than environmental outcomes, social outcomes are linked to a growing population, employment, and income growth - economic and social factors are tightly intertwined. When environmental outcomes hold more weight, negative social outcomes related to forced lifestyle changes, loss of access to nature, and unhealthy living conditions are given more emphasis. Social factors also link to aspirations and hopes for the future. In the Pajala case, the positive economic outcomes offered the possibility for a brighter future for a community in decline.

However, despite the relatively successful economic developments at the local level, the mine still failed. Some of the discussions at the local level had raised the issue of the potential for bankruptcy and the uncertainty that would follow. But in our data, none of the bankruptcy discussions questioned or were critical of the mine in general. Given the demographic decline experienced by the municipality, this is not completely surprising as the local residents looked at any economic development as creating new opportunities for the municipality.

But the growing economy was at the mercy of volatile global commodity markets and international investors. Given that the population of Pajala was already relatively small at about 6000 , the rapid injection of mine related employment created a very fragile employment and economic environment for the municipality. This was exacerbated by iron ore prices that steadily decreased during the operation of the mine. In the fall of 2014, this vulnerability became painfully clear when Northland's 
bankruptcy was declared. The mining operation was shut down and hundreds of workers at the mine as well as in ore transport were terminated. Examining the reasons for the Kaunisvaara mine's failure is beyond the scope of this paper, but the bankruptcy is typically attributed to significantly overrun capital costs to develop the project, combined with the unfortunate timing of falling iron ore prices.

Since shutting down operations, an officially appointed 'receiver' (or trustee) has assumed control over the company and worked to secure the sale of Northland's assets, as iron ore prices have remained low. Media reports have chronicled the community's hope that a new owner would continue operations at the mine site, and conversely, their fear that the processing plant would be dismantled, the equipment shipped away, and the mine reduced to a hole in the ground. These fears were also emphasized in our interview with the local Chamber of Commerce, conducted in the spring of 2015. In the summer of 2015, a group of private Swedish investors acquired the processing plant and other mining equipment (but not the mine itself). This group reportedly intended to resume operations and had acquired the equipment to avoid it being sold off and scattered. ${ }^{31}$ Since then, the mine has remained closed, but the hope that a new operator will appear and revive the local economy persists.

So, while conditions for positive economic development in the municipality appeared to be present, they rested on a knife's edge and very little to none of the discussions about developing the mine revolved around its viability in a situation of decreasing global commodity prices. Perhaps more importantly, the development stage of the mine appeared to be without issue - at a time when planning on historically high iron prices should have been called into question. If residents of the municipality had been more thoroughly informed not only about the potential economic benefits of the mine, but also about some of the risks in the current economic climate, their attitudes towards the mine may have been different.

This raises interesting debates over whom, if anyone, should bear responsibility for bringing such issues to light? The degree of planning for a major development, such as a mine, requires multiple government ministries and agencies at different levels to approve, or at least be aware of, the proposed operations. Should one of these entities be responsible for ensuring companies propose more conservative business plans? Or, in cases of higher risk, should reporting and information dissemination become more robust?

\section{Conclusion}

Legitimacy requires that the population affected by decisions see merit in the processes and outcomes. In this case, as expected with resource development, the positive, legitimizing attributes were heavily skewed towards economic outcomes and the negative, delegitimizing attributes fell on the environmental side. In debates on sustainable development, this result is not surprising. However, where social outcomes fit into the equation becomes very interesting. While most communities welcome 
economic growth, the social changes that accompany economic growth often receive mixed reception. Population growth is associated with better services and amenities, but also with increased crime and a deterioration of societal trust. However, when it comes to communities in desperate need of economic stimulus, the perspectives on social outcomes sit heavily on the positive side.

With respect to legitimacy and the link between expectations and reality, the legitimizing factors identified by the respondents matched the empirical reality closely. That the mine brought economic growth, local jobs, and benefitted small businesses, while it was operational, made a significant impact regarding the legitimacy it held in the community. Importantly, these economic outcomes do not hold sole responsibility for legitimizing the mine, because the approach the company used to engage the community also affected local perceptions and trust; we believe the circumstances facing the community prior to the mine opening pushed these factors to the fore.

However, a case of strong legitimacy does not ensure that outcomes endure. In the case of Pajala, it appears that economic benefits were not measured against economic risks. When considering the significant impact mine development creates for a small municipality, the legitimacy of or support for the mining project focuses strongly on local issues. On the one hand, this is understandable because municipal governments and municipal issues generally focus more on population growth and employment levels, both of which fall within their purview. On the other hand, global economic trends can undermine relationships and trust at the local level, potentially eroding legitimacy.

Pajala is a cautionary tale. The project was perceived as legitimate by local residents, but still failed. Therefore, one could make the argument that different issues needed to come to the fore during the development and operation of the mine, and the goodwill earned by the company needed to be based on a broader set of merits. More generally, this speaks to the tenuous legitimacy resource development projects rest upon. While companies, communities, and governments may engage in projects with the best of intentions, factors completely outside of their control may put an end to the work.

\section{NOTES}

1. Bridge, G (2004) “Contested terrain: Mining and the environment.” Annual Review of Environment and Resources, 29: 206.

2. Littig, B., Griessler, E., 2005. Social sustainability: a catchword between political pragmatism and social theory. Int J Sustainable Development 8, 65-79.

3. Beetham, D. (2013) The Legitimation of Power. Hampshire: Palgrave Macmillan.

4. Suchman, M. C. (1995) "Managing Legitimacy: Strategic and Institutional Approaches." The Academy of Management Review vol. 20, no. 3: 571-610.

5. SGU (2013). Vägledning för prövning av gruvverksamhet. Dnr 04-2288/2012. Sveriges geologiska undersökning, Uppsala.

6. Ibid.

7. Elenius, L (2008). Transnational history and language barriers. In: A baseline study of socio-economic effects of Northland Resources ore establishment in northern Sweden and Finland. Department of Human Work Sciences, Luleå University of Technology. 
8. ÅF Infraplan (2011). Kvinnounderskott i Pajala - åtgärder och konsekvenser. Rapport till Pajala Utveckling AB, ÅF Infraplan, Tavelsjö.

9. For instance by the national newspaper Svenska Dagbladet (2010).

10. Jakobsson, M. (2008). Preferences about present situation and future expectations in Pajala and Kolari. Luleå University of Technology, Department of Human Work Sciences.

11. Weber, M. (1964). The Theory of Social and Economic Organization, Talcott Parsons (ed.), New York: Free Press.

12. Bryson, J. M. (2004) "What to do when Stakeholders Matter: Stakeholder Identification and Analysis Techniques." Public Management Review vol. 6, issue 1:21-53.

13. Beetham, D. (2013) The Legitimation of Power. Hampshire: Palgrave Macmillan: 29.

14. Birch, A. H. (2001) Concepts \& Theories of Modern Democracy. London: Routledge.

15. Parkinson, J. (2003) "Legitimacy Problems in Deliberative Democracy." Political Studies vol. 51: 180-196.

16. Stoker, G. (1998) “Governance as Theory: Five Propositions.” International Social Science Journal 50 (155): 17-28.

17. North, D. "Institutions." The Journal of Economic Perspectives vol. 5, no. 1: 97-112. See also: Ostrom, 2005; Rothstein, 200; March \& Olsen, 2004; Widegren, 1998.

18. Suchman, M. C. (1995) "Managing Legitimacy: Strategic and Institutional Approaches." The Academy of Management Review vol. 20, no. 3: 574.

19. Beetham, The Legitimation of Power.

20. Scharpf, F.W. (1999) Governing in Europe: Effective and Democratic? Oxford: Oxford University Press.

21. Stimson, R.J., Stough, R.R., and Roberts, B.H. (2006). Regional Economic Development. Analysis and Planning Strategy. Second Edition. Springer, Heidelberg. (See also: Haynes, K.E., and Parajuli, J. (2014). Shift-share analysis: decomposition of spatially integrated systems. In: Stimson, R. (Ed.). Handbook of Research Methods and Applications in Spatially Integrated Social Science. Edward Elgar Publishing Ltd. UK.

22. Ibid, Stimson et al., 'Regional Economic Development. Analysis and Planning Strategy'.

23. E.g. Dinc, M. (2002). Regional and Local Economic Analysis Tools. Report prepared for the Public Finance, Decentralization and Poverty Reduction Program, World Bank Institute. The World Bank, Washington,DC.

24. See for instance Barff, R.A., and Knight III, P.L. (1988). Dynamic shift-share analysis. Growth and Change, 19(2), 1-10.

25. Ibid, Barff and Knight, 'Dynamic shift-share analysis'.

26. Mitchell, W., and Carlson, E. (2005). Exploring employment growth disparities across metropolitan and regional Australia. Australasian Journal of Regional Studies, Vol. 11, No. 1, 25-40.

27. Hirobe, T. (2015). Economic shift-share effects and spatial agglomeration regarding inter-regional disparities of labour market in the USA. Regional Science Policy \& Practice, Vol.7, No. 3, 103-118.

28. Otsuka, A. (2016). Regional energy demand in Japan: dynamic shift-share analysis. Energy, Sustainability and Society, 6:10. DOI 10.1186/s13705-016-0076-x.

29. Ibid, Stimson et al., 'Regional Economic Development. Analysis and Planning Strategy'.

30. Swedish Board of Agriculture (2013). Yearbook of Agricultural Statistics 2013. Statistics Sweden, Agriculture Statistics Unit, Örebro, Sweden.

31. As reported by the newspaper Dagens Nyheter (2015). Finanskändisar köper delar av Northlands konkursbo. Available at: http://www.dn.se/ekonomi/finanskandisar-koper-delar-av-northlands-konkursbo/ (Accessed September 30, 2015).

32. Ibid, Mitchell and Carlson, 'Exploring employment growth disparities across metropolitan and regional Australia'

33. Ibid, Barff and Knight, 'Dynamic shift-share analysis'. 


\section{Gregory A. Poelzer E Thomas Ejdemo}

\section{References}

Barff, R.A., and Knight III, P.L. (1988). "Dynamic shift-share analysis". Growth and Change, 19(2), 1-10.

Beetham, D. (2013) The Legitimation of Power. Hampshire: Palgrave Macmillan.

Birch, A. H. (2001) Concepts \& Theories of Modern Democracy. London: Routledge.

Bridge, G (2004) "Contested tertian: Mining and the environment." Annual Review of Environment and Resources, 29: 205-259.

Brunnschweiler, C.N.; Bulte, E.H. "The resource curse revisited and revised: A tale of paradoxes and red herrings." Fournal of Environmental Economics and Managements vol. 55: 248-264.

Bryson, J. M. (2004) "What to do when Stakeholders Matter: Stakeholder Identification and Analysis Techniques." Public Management Review vol. 6, issue 1:21-53.

Butkiewicz, J. L.; Yanikkaya, H. (2010) "Minerals, Institutions, Openness, and Growth: An Empirical Analysis”. Land Economics, 86 (2); 313-328.

COM, 2013. Report from the Commission to the European Parliament, the Council, the European Economic and Social Committee and the Committee of the Regions on the Implementation of the Raw Materials Initiative. Com 442.

Dinc, M. (2002). Regional and Local Economic Analysis Tools. Report prepared for the Public

Finance, Decentralization and Poverty Reduction Program, World Bank Institute. The World Bank, Washington, DC.

Elenius, L (2008). “Transnational history and language barriers”. In: A baseline study of socio-economic effects of Northland Resources ore establishment in northern Sweden and Finland. Department of Human Work Sciences, Luleå University of Technology.

Haynes, K.E., and Parajuli, J. (2014). "Shift-share analysis: decomposition of spatiallyintegrated systems". In: Stimson, R. (Ed.). Handbook of Research Methods and Applications in Spatially Integrated Social Science. Edward Elgar Publishing Ltd. UK.

Hirobe, T. (2015). "Economic shift-share effects and spatial agglomeration regarding inter-regional disparities of labour market in the USA". Regional Science Policy \& Practice, Vol.7, No. 3, 103-118.

ICMM, 2012b. Community development toolkit. International Council on Mining and Metals. Available at http://www.icmm.com/document/4080.

Jakobsson, M. (2008). Preferences about present situation and future expectations in Pajala and Kolari. Luleå University of Technology, Department of Human Work Sciences.

Leigh, R. (1970). "The Use of Location Quotients in Urban Economic Base Studies". Land Economics, Vol. 46, No. 2, s. 202-205.

Littig, B., Griessler, E., 2005. "Social sustainability: a catchword between political pragmatism and social theory". International fournal of Sustainable Development 8, 65-79.

Mitchell, W., and Carlson, E. (2005). "Exploring employment growth disparities across metropolitan and regional Australia". Australasian fournal of Regional Studies, Vol. 11, No. 1, 25-40.

Moffat, K., and A. Zhang. (2014) "The Paths to Social License to Operate: An Integrative Model Explaining Community Acceptance of Mining." Resources Policy 39: 61-70.

Moreen, A, L. (2006) Overcoming the 'Resource Curse': Prioritizing Policy Interventions in Countries with Large Extractive Industries. PhD Thesis: RAND Corporation.

North, D. "Institutions." The fournal of Economic Perspectives vol. 5, no. 1: 97-112.

NSD (2016). Ministerns löfte till Rantakyrö. NSD, February 2, 2016. Report in regional newspaper. Internet: http://www.nsd.se/nyheter/tornedalen/ministerns-lofte-till-rantakyro-9837954.aspx (accessed May 8, 2016).

Ostrom, E. (2005) Understanding Institutional Diversity. Princeton: Princeton University Press.

Otsuka, A. (2016). "Regional energy demand in Japan: dynamic shift-share analysis". Energy, Sustainability and Society, 6:10. DOI 10.1186/s13705-016-0076-x.

Parkinson, J. (2003) "Legitimacy Problems in Deliberative Democracy." Political Studies vol. 51: 180-196.

SGU (2013). Vägledning för prövning av gruvverksamhet. Dnr 04-2288/2012. Sveriges geologiska undersökning, Uppsala.

Schaffer, W.A. (1999) Regional Impact Models. Regional Research Institute, West Virginia University.

Scharpf, F. W. (1999) Governing in Europe: Effective and Democratic? Oxford: Oxford University Press.

Stimson, R.J., Stough, R.R., and Roberts, B.H. (2006). Regional Economic Development.Analysis and Planning Strategy. Second Edition. Springer, Heidelberg. 
Stoker, G. (1998) “Governance as Theory: Five Propositions”. International Social Science fournal 50 (155): 17-28.

Suchman, M. C. (1995) “Managing Legitimacy: Strategic and Institutional Approaches." The Academy of Management Review vol. 20, no. 3: 571-610.

Svenska dagbladet (2010). Pajala hoppas ge järnet med gruvan. Internet: http:/www.svd.se/pajala-hoppas-gejarnet-med-gruvan (accessed May 8, 2016).

Swedish Board of Agriculture (2013). Yearbook of Agrucultural Statistics 2013. Statistics Sweden, Agriculture Statistics Unit, Örebro, Sweden.

Widegren, O. (1998) "The new environmental paradigm and personal norms." Environment and Behavior 30 (1), 75-100.

ÅF Infraplan (2011). ”Kvinnounderskott i Pajala - åtgärder och konsekvenser”. Rapport till Pajala Utveckling AB, ÅF Infraplan, Tavelsjö. 


\section{Appendix}

\section{Technical description of the shift-share method}

The shift-share analysis presented in section 4 is based on data collected from Statistics Sweden on local (municipality), regional (county) and national employment for the years 2009 to 2014 . The data is organized in 16 different industries according to the SNI 2007 classification (see Figure 3 for an overview). Following Mitchell and Carlson, ${ }^{32}$ if $E_{\mathrm{t}}$ designates national (or county) employment at time $t$, the employment growth rate is defined as:

$$
g_{n t}=\left(E_{t}-E_{t-1}\right) / E_{t-1}
$$

The industry specific growth rate for industry $i$ at the national (or county) level at time $t$ is defined as:

$$
g_{\mathrm{i} n t}=\left(E_{t}-E_{i t-1}\right) / E_{i t-1}
$$

And the employment growth rate for industry $i$ in region $r$ (here designating the local growth rate) at time $t$ is defined as:

$$
g_{\text {irt }}=\left(E_{i r t}-E_{\text {irt-1 }}\right) / E_{\text {irt-1 }}
$$

As described above, shift-share analysis decomposes the employment change for region $r$ and industry $i$ into three components: (a) national growth effect (NS), (b) industry mix (IM) and (c) the regional/local effect (RS). The shift-share framework can thus be expressed as:

$$
\Delta E_{i r t}=\left(N S_{i r t}-I M_{i r t-1}\right) / R S_{i r t}
$$

For each industry $i$ in region $r$, the three components are defined as:

$$
\begin{aligned}
& N E_{i r t}=E_{i r t} g_{n t} \\
& I M_{i r t}=E_{i r t}\left(g_{i n t}-g_{n t}\right) \\
& R S_{i r t}=E_{i r t}\left(g_{i r t}-g_{i n t}\right)
\end{aligned}
$$

The traditional shift-share analysis is comparative static in its approach. Typically, such an analysis compares the first and final years of a time period covering several years. ${ }^{33}$ This comparative static approach has been widely used in regional economic analyses since the 1960s, but it is associated with a range of limitations. Barff and Knight provide a review of these limitations noting that the approach fails to account for continuous changes in the industrial mix and in the size of total employment of the region over the study period. To overcome some of the limitations associated with the traditional specification, Barff and Knight proposed a dynamic approach where shift share components are computed annually and summarized over the study period, thereby accounting for temporal changes in industry structure as well as total regional employment. This dynamic approach was employed in section 4 of this paper. 